\title{
Shariah and Evolution of fair Trial Rights in Pakistan
}

\author{
*Muhammad Iqbal \\ "Dr. Khursheed Iqbal
}

\section{ABSTRACT:}

"Since Islam is the guiding principle for the process of law formation in Pakistan, it is but established that introduction of article 10-A in Constitution of Pakistan guarantees right to fair trial and due process is an extension of rights provided in Islam. Two major landmarks in legislation have been the vision of our nation's father Muhammad Ali Jinnah and the subsequent "Objective Resolution" which acted as a universally accepted guideline for all the future legislation in Pakistan. The second serious effort was made during Zia's era (1977-88) when religious scholars and lawmakers sat together to amend existing laws according to Islam. How successful these attempts were, is debatable to date, but it certainly had a lasting effect the consequences of which can be seen not only today but in future legislation as well.

Keywords: shariah, Islam, Law, Rights, Pakistan.

\section{Sources of Law in Islam}

"One out of the only two states in the world which came into being on religious ideology (the other being Israel), Islam since the first day has been taken implicitly as well as explicitly, the guiding principle of all walks of life including legislation. This was expressed many times by our Quaid-e-Azam Muhammad Ali Jinnah at numerous occasions before the birth of our nation. Being a country with over 90 percent Muslim population, it is considered imminent that laws should follow the guidelines of Islam. But we cannot ignore the historical development of law in the region which has the influence of multiple geographical and socio-economic factors as well as the amalgamation of laws that were brought by subsequent attackers over centuries. Since Pakistan came into being when British were the ruling elite of subcontinent, common law was followed in 1947 which naturally flowed into the legal fabric of Pakistan with minor adjustments". In order to understand what Islamic Shariah and jurisprudence means, sources of Islamic law needs introduction.

\section{Shariah in Islam}

Shariah literally means 'road' or 'highway'. Its derivation means the beaten track where wild animals come down to drink at their watering place. It refers to the path where waters of life (knowledge and understanding) flow inexhaustibly. ${ }^{1}$ Shariah has been the source of adherence amongst the Muslim society and the guidance for not only its submission to Allah almighty but rules to govern and live in the society. According to Von Grunebaum: for the Muslims, from ninth to nineteenth century, time stood still, and the world was stayed on its centrifugal course. One thing alone

*Ph.D Scholar / District \& Session Judge, Anti-Terrorism Court Lahore.

Email: c.muhammadiqbal@gmail.com

"District \& Sessions Judge, Former Director General KP Academy. 
made this possible, the adherence of society as a whole......to the Shariah, the religious law of Islam. ${ }^{2}$

The main purpose of Shariah is to guide human's search for the truth through a set of laws, hence it touches on both transcendent and material experience. Theoretically speaking, this has also been the ultimate goal of trial conduction in legal spheres. ${ }^{3}$ Shariah cannot be called with strict accuracy as body of revealed laws. The reason being rational judgment and human effort has contributed in the development of Shariah and this judgment is considered by Muslims as an enlightened contribution aided by divine help. ${ }^{4}$

\section{Quran and Sunnah Basic Law Sources}

Holy Quran is the ultimate 'Constitution' of Islamic community, words of which are immutable for Muslims, who are bound to obey and follow them in letter and spirit. Shariah consisting of Quran and Sunnah as the first two sources, is the code which has made the message of Quran and Sunnah for Muslims into a law that is livable and is practical. 5 "Quran being the divine book of Muslims is not regarded as legal code but gives basic legal guidelines rather than strict legal rules. Although these guidelines cover all aspects of legal arena from arrest, conviction, trial, sentencing and all other aspects, the exact number of legal texts are still not confirmed by the religious scholars. ${ }^{6}$ The text in Quran, both legal as well as non-legal dealt mainly in the subjects of zakat, rights of orphans, homicide, usury, property, inheritance, marriage, rights of women, polygamy, divorce, adultery, prohibition of alcohol, halal and haram foods etc.,. "The second primary source of Islamic law is Sunnah which constitutes sayings, deeds and unspoken approvals by the Prophet (P.B.U.H). Other than what is narrated by the companions of the Prophet (P.B.U.H), the Sunnah also includes everything including the physical features and traits. The Quran and the Sunnah complement each other. The Quran is the word of Allah, whereas the Sunnah is its practical interpretation. ${ }^{8}$ The Sunnah also gives a full account of the life of the Prophet (PBUH). The Quran principally deals with basic instructions whereas Sunnah provides necessary explanations and details of those Quranic verses. ${ }^{9}$

There was nothing more important for Muslims to ensure what Prophet Muhammad PBUH said in guidance to the newly emerging society. For this purpose, religious scholars of $2^{\text {nd }}$ and $3^{\text {rd }}$ centuries of Islamic era compiled six books of authentic hadith based mainly on human value of individual 'transmitters' of hadith. The authenticity of hadith was established with painstaking care and detail. The 'Mujtahideen' would go to any lengths to ensure that there is no single weak link to 'break the chain' of authenticity.

\section{Secondary Sources of Law}

The word "fiqh" means 'jurisprudence', comes from the verb "faqiha" means 'he understood'. "Eaton is of the view that the establishment of hadith by the four schools of law was the first step in the complex and long process of legislation. Legal provisions drawn directly from Quran and Sunnah could not be expected to neither cover every contingency nor the requirements of great Muslim empire and its bustling cities. ${ }^{10} \mathrm{~A}$ body of law was formed to address every imaginable situation and occurrences, without 
losing sight of its sacred and impeachable sources." For this purpose, three principal methods were adopted.

a. Intellectual effort (ijtihad) (individual effort of mujtahid).

b. consensus (ijma) (collective work of mujtahideen),

c. analogy (qiyas),

When facing a certain legal issue and there are no clear-cut instructions regarding that problem, ijtihad or ijma is sought. Although sources of law are hierarchically applied to a problem, ijma is considered as third source after Quran and Sunnah. While ijtihad is the individual decision of a man with sufficient Islamic knowledge or jurist (mujtahid), ijma, on the other hand, is the consensus of mujtahideen (jurists) on an inquiry of law during a certain time period. ${ }^{11}$ Mujtahideen can rightly be called as the earliest architects of Islamic law, as they were the "scholars of Hadith" too. ${ }^{12}$ Since ijma is supported by verses of Quran and Sunnah, it is considered as lawful and binding. The Quran says, "Obey Allah and obey the Messenger, and those charged with authority among you". ${ }^{13}$ Similarly, the Prophet said, "my community will never agree upon an error". ${ }^{14}$ which gave a guaranteed soundness to any consensus reached amongst the Muslim community. Although it is generally accepted to be the ijma between the scholars of Islam followed by the general public, but examples are also present when the opinion of Muslim masses was followed by ulema of that era. When coffee was first introduced as a beverage, it was pronounced by ulema as prohibited, but the disagreement of general public changed the view of scholars and coffee was legitimized in due course of time.

Qiyas, (qiyās in arabic) is the analogical reasoning applied to a certain issue which is not covered by Quran, sunnah or ijma. Considered as a specific variant of ijtihad, qiyas was used to deduce new opinions and practices on the basis of analogy with past practices and beliefs. Modern scholars are of the view that istihsan is like equity but is based on shariah while equity is based on natural law. ${ }^{15}$ Qiyas has following set of circumstances to be dealt with namely ${ }^{16}$

1) Qiyas of superior order (al-Qiyas al-Awla):

2) Qiyas of an equal order (al-Qiyas al-Musawi):

3) Qiyas of a lesser order (al-Qiyas al-Adna):

All four sources of Islamic law are established to provide clear guidance in every matter of a Muslim's life. Similarly, the right to fairness in trial is also adequately explained by these sources as essential rights are not only protected but guaranteed in Shariah.

\section{Islamic Law and Right to Justice and Fair Trial}

"Islam as a legal doctrine establishes justice through Shariah. The standards of justice in Islam surpass all discrimination and is a balance between the obligations and rights. Shariah provides protection to all and sundry without discrimination. Through Shariah, Islam provides protection of life, liberty, religion, intellect, property, lineage and dignity. ${ }^{17}$ Islam as seen since the first century of Islamic calendar has endowed a certain privacy and protection to the individuals of the society where Muslims need law of Shariah not to tell them what to believe but how to believe and live life 
according to the divine laws. Quran and Sunnah along with secondary sources of law provide elaboration and authority to these guidelines. These norms and principles are acknowledged and expressed by Muslim jurists as legal maxims (qawaid kulliyah) that describe the objectives and purposes of Shariah. The negligence in protection of these rights or any imbalance between them can cause a society to expose people to danger and collapse at the cost of justice in the society. ${ }^{18}$

The idea of Islam is that of a community in which every individual lives within the relationship of Allah and the mold of circumstances provided to him under the rule of law. The community sheltered and ordered by the Shariah has the sources of law as a 'part of faith'. ${ }^{19}$ This community requires a balanced approach of rights and obligations into the fabric of justice. Islamic concept of law between the rights of individuals and their Creator 'places many paths in which humans select in conformity of their needs and live according to the Divine norm as indicated by Shariah' ${ }^{20}$

\section{Human Rights: Islamic Law Perspective}

Right to fair trial is a fully developed concept in Islamic law which not only provides judicial and social mechanism for attaining truth and fairness during trial but also create a balance of rights between the accused and the victim. Islam not only provides legal remedies but also examples of court decisions based, theoretically speaking, on ethical values of Muslim society which determines truth during the chronology of events of a trial. The incentive of doing good deeds and intentions in Islam is further cemented by the concept of reward in the 'hereafter', which served as an impetus for enforcement of the Human Rights is an Islamic State. Being a welfare state, Islamic society put great value on preserving and promoting morals and human rights within its community. 'Shariah is divided into the rights of God and the rights of the people, where the rights of God are also linked to the benefit of the mankind. It has been stated by the scholars that': ${ }^{21}$

Rights of former class (i.e. Rights of God) are such as involve benefit to the community at large and not merely to a particular individual......the rights of God correspond to public rights and since the Mohammedan Law regards the observance of obligatory devotional acts as being beneficial to the community there is no difficulty in describing all rights of God as 'Public Rights'. ${ }^{22}$

Being a complete code of life, the rights of mankind, according to Shariah are innumerable and results in a complete system of life. Not only Quranic verses give divine commands but the last sermon of the Holy Prophet (P.B.U.H) is regarded as "the first comprehensive charter found on the basic fundamental rights of man". ${ }^{23}$

The right personal freedom in Islam conforms to regulations within divinely ordained pattern but free within the personal life from the societal pressures and the impositions of the state other than those prescribed in sources of Islamic law. The doctrine of Shariah rather than a straitjacket of strict laws, is a flexible framework with adequate space for free movement and individual differences. These and many other rights of protection against arbitrary arrest and detention, and protection of dignity of man as well as right to lawful retribution (Qisas) have been provided with 
much clarity in Islam. Being one of the basic principles of Islamic jurisprudence, law remains aloof disregarding caste, creed, social status or monetary position of a person in society. Justice should be meted out without any favouritism or prejudice.

These are a few of rights given in Islamic jurisprudence. Clearly, the divine system given in Islam even centuries ago was not only complete, sophisticated but up to date for all the times to come. This classic quality of Islamic law has the effect that all the major constitutions of the world have reverberated provisions of Islamic jurisprudence to some extent. How Pakistani legal scenario is adapting to the Islamic provisions provided by Shariah keeping in view the geographical and socio-cultural norms will be discussed below.

\section{Creation of Pakistan and Objective Resolution}

The idea of inception of Pakistan was based on the ideology that Muslims need a homeland where they are free to practice their doctrine of Islam with no fear of reprisal. The idea of a state where the basic legal rights of all inhabitants would be equal and within the conformities of Islam was the major inspiration and reason behind the creation of this state. Quaid-e-Azam Muhammad Ali Jinnah as well as the founders of Pakistan envisioned this state to be a modern Islamic state where Islamic law would be supreme. In his speech to the first Constituent Assembly, Jinnah said, 'the first duty of a government is to maintain law and order, so that the life, property and religious beliefs of its subjects are fully protected by the State' ${ }^{24}$ From the very start, there has been two groups of modernist and religious activists, with opposing opinions regarding whether the country would be run as a secular state or a religious one ruled by the Shariah. This conflict has more to do with ignorance of the Islamic history where Shariah being a complete code of life gives more personal liberty and choices than any other system of governance based on religion. As discussed before, the Islamic system of governance stayed almost static from $9^{\text {th }}$ to $19^{\text {th }}$ century owing to the personal liberty a person enjoyed along with the protection the state provided..$^{25}$ The same concept was also adapted by the Constituent Assembly when Objective Resolution was presented as a guideline for the future Constitutions and legislation in Pakistan. In this resolution, the sovereignty of everything and everyone was attributed to Allah Almighty., which the people of Pakistan will use as a sacred trust and within the limits described by Him. This declaration laid down the basics of Islamic ideology and the Islamic principles of democracy, equality, fairness and social justice and cultural protection of all citizens including religious minorities for the future law formulation in Pakistan. The objection of some non-Muslim members of Constituent Assembly that the proclamation of sovereignty of Allah would be contrary to the democratic nature of the new state, was settled down by members of the assembly on the argument that Pakistan was essentially not a theocratic state, ${ }^{26}$ rather many constitutions of the world including USA and Ireland are working under similar words and beliefs. ${ }^{27}$ Moreover, representative democracy was not ruled out by the objective resolution. ${ }^{28}$ The objectives resolution, with minor amendments, was adopted as a preamble and guideline to the ideology of Pakistan to all the subsequent constitution of Pakistan. 
Later on, through article 2-A, it was made a substantive part of the constitution. ${ }^{29}$ Although in case of Zia-ur-Rehman case, Supreme Court held Objective Resolution to be a preamble of the state. ${ }^{30}$ Yet this preamble initially became the guiding force for all the Constitutions adopted in Pakistan and later became an integral part of Constitution of Pakistan 1973. Due to the importance attached to this resolution, all three constitutions of Pakistan adopted these Islamic provisions, albeit minor differences in similar way.

\section{The Islamic Provisions of the 1973 Constitution}

As Islam is the state religion of Pakistan, the Constitutional name of the country is also Islamic Republic of Pakistan. The set of laws and legal traditions which Pakistan inherited in 1947 was an amalgam of religious (Islamic and laws of ancient cultures like Hinduism) and cultural traditions with a major portion of legal traditions following common law in United Kingdom under the British Crown. It was but a natural demand that all existing laws shall be made in accordance with the teachings and guidelines of Islam $^{31}$ and no law shall be decreed which is unacceptable to such injunctions. ${ }^{32}$

Although the recommendations by the objective resolution and the Islamic provisions were adopted in all the three Constitutions of Pakistan, a big support to this adoption was also the rights provided in international covenants and statutes at international organizations around the same time line starting from 1945 to 1948 (the year UDHR was adopted) and so on. Yet one of the biggest challenges was the successful legislation where laws had practicality to it and the implementation of these laws at individual as well as national level. These adoptions are also claimed to be a sort of compromise between the modernists and the Islamic activists and thus the clear and precise definition of concept of Islamic state was not provided. ${ }^{33}$ Also, the ideology Council is tasked with making Islamic laws as well as adapting existing laws according to Islamic provisions have no binding effect on the Government, thereby reducing it to a mere suggesting body. ${ }^{34}$

The successive governments in Pakistan, belonging to different modes of governance, has personal preference and liking evident in constitutional amendments, especially in case of Islamization of existing laws. For example, Ayub' era was marked by the efforts of modernizing the legal system with a secular mindset but faced backlash from the religious elements of the government and society and had to take back the proposed amendments. Out of the three constitutions of 1956, 1962 and 1973, the tilt towards Islamization for legislation was most profound with maximum Islamic provisions in the constitution. ${ }^{35}$ Another shift of preferences was very evident during Zia's regime when extensive efforts were made not only for the implementation of Islamic provisions of the Constitution of 1973 but new constitutional reforms were introduced as well. Despite conflicting efforts regarding Islamization of the legal doctrines, the debate between the modernists and the activists has escalated further. The question of Islamization of legal system is still not only unanswered but the gap of trust amongst them is increasing. One reason for this is that, like in all regions of the world, poorer masses are more religion oriented and Pakistan being a third world country, has its majority 
of people's sympathies with the activists. As war against terrorism is started against those elements who had played the religion card to gain sympathies, the society has split into two opposing opinions and a sharp demarcation can be seen amongst the society. This division has repressed the hope of a unified opinion regarding adoption of Islamic principles of social justice. The international instruments also view the Islamization of legal system in Pakistan with divided opinion and suspicion as the real spirit of Islamic law is either hidden or misinterpreted to them. ${ }^{36}$ In such a scenario, the implementation of an international instrument, like the declaration, in Pakistan requires a proper theoretical understanding of the Islamic principles of social justice. ${ }^{37}$

\section{Islamization and Criminal Judicial System in Pakistan}

The echo of Islamization of Pakistan's legal system has been heard from time to time since independence. This effort gained governmental support in 1980 with the establishment of Federal Sharia Court through constitutional amendment, ${ }^{38}$ carrying forward the same task as of Shariat benches regarding Islamization of legislation. ${ }^{39}$ This movement of Islamization was mainly focused on judicial, economic and educational sectors.

In early 1979, Zia announced several reformations in an effort of molding the society more towards Islamic principles, an overall environment was introduced in the country which was named by the critics as Islamization in Pakistan. Many measurements like offering namaz, respecting Ramazan through special ordinance and facilitating maximum people to perform Hajj were also introduced. These efforts were welcomed by the general public but perhaps the most controversial were the Hadood laws in which four punishments were announced dealing with theft, adultery, false accusations and drinking. Punishments of cutting hands, whipping with lashes and stoning to death accompanied Hadood laws. ${ }^{40}$ Although these punishments were according to Islamic principles of Shariah and according to many critics like Gai Eaton, much less than the punishments meted out during mediaeval times in Europe, ${ }^{41}$ yet there was an element of initial shock accompanied with fear for the general public. Appeal to these punishments can only be made at Shariat Court. The law of whipping was abolished in 1996 except in Hadd cases of adultery. ${ }^{42}$ Yet these strict punishments were only implemented if undeniable proof of evidence was provided to the court. Similarly, pregnancy was also considered a proof of adultery for women. ${ }^{43}$ Theft and armed robbery are punishable with amputation of a hand. In 1984, the Evidence Act 1872 was revised and was given the name of Qanoon-e-Shahadat Act $1984 .{ }^{44}$ Similarly, Parliament was given the name of 'Majlis-e-Shoora' and Objectives Resolution was declared a substantive part of the Constitution of Pakistan 1973. On $15^{\text {th }}$ June 1988, a Shariat Ordinance was promulgated declaring Shariah as the supreme law in Pakistan. It was made obligatory that any documented evidence regarding financial transaction or agreement between the parties must be countersigned by either two adult and sane men or one man and two women who are adults, to keep as a documentary evidence along with witnesses. ${ }^{45}$

Zia's death just two months after declaring the Shariah Ordinance apparently stopped the process of Islamization. One of the reasons was the political instability and the 
economic Chaos the country was facing at that time. Some argue that despite, the personal tilt of Zia towards Islam, the process of Islamization was used more for the political gains in which too much emphasis was put on punishments rather than the true picture of universality and peaceful progress and protection for individuals in the society, which had remained the hallmark of Muslim society for many centuries. Whether the intentions of General Zia were true to their cause or not, but the lack of strategy, planning and then ineffective implementation turned this half-cooked effort into a set of legislation which could not be further from the true spirit of Islam.

After Zia's death in 1988 the efforts to shift legislation towards Islamization continued. In 1988, President Ghulam Ishaq Khan also implemented an amended 'Shariat Ordinance'. The Senate also proposed a 'Shariat Bill' in 1990 but was not passed by the senate. In 1990, the 'Qisas and Diyat Ordinance' was introduced. Similarly, the Parliament also passed the Enforcement of Shariah Act in 1991.

Despite the fact that Federal Shariat Court was initially considered a powerful and authoritative court where the appeal as well as revision against punishments awarded by ordinary courts can be made, yet the jurisdiction of this court remined constrained. ${ }^{46}$ These efforts by Zia were not able to bring the desired results and this legislation was not fruitful as it did not bring any substantive change. Just like the Man, the Boy and the Donkey in Aesop's Fables ${ }^{47}$ neither Ulema nor modernists and neither the general public accepted the Islamization without criticism. All these groups considered these attempts maligned with the personal gain and attempt to have firmer grip on the rule in Pakistan. The Hadood laws raised much hue and cry and overshadowed all the good efforts in promoting the true essence of Shariah in Pakistan. This legal scenario continued till 1999 when the regime of another military general took a somersault view against the Islamization of Zia's regime. General Musharraf 1999-2008 not only discontinued Islamization, but also made successful attempts to nullify the reforms introduced by Zia. The introduction of Women Protection Act in 2006, despite protests of the religious scholars, proved to have radical effects on the society. ${ }^{48}$ General Musharraf also challenged the constitutionality of Hasba Bill that was introduced twice by the religious parties in provincial legislature. ${ }^{49}$

\section{Prospects and Challenges of Fair Trial in Pakistan}

Although Objective Resolution clearly marked the direction of legislation in Pakistan in 1949, it was in late 1960s that courts in Pakistan started increasingly recognizing and relying on the principles of Shariah, disregarding the customs of the land that had cultural influences. ${ }^{50}$ Numerous examples were present during that era. For example, Supreme Court decided that it was un-Islamic for a woman to relinquish part of her inheritance in favor of her male relatives. Similarly, a well-off person was advised to take care of his poor relatives within the prohibited degrees (blood relations, to whom marriage is not permitted under Islamic law). ${ }^{51}$

Justice Cornelius in his judgment in 1970 was of the view that, 'in Pakistan the concept of the rule of law should indicate nothing else than Shariah'. ${ }^{52}$ The jurisprudence of the Court in the Hudood laws introduced by General Zia is inconsistent. This can partly 
be attributed to the fact that courts in 1991 were allowed the additional role of "mujtahid". The empowerment of courts by the introduction of Shariah Act 1991 has allowed the courts to do "judicial Ijtihad". ${ }^{53}$ In several cases, the Federal Shariat Court amended the verdicts of the lower courts in different cases, for example, that a case of rape cannot be changed to that of zina $^{54}$ and the absence of marks of violence on the body of victim is not a guarantee of no crime. ${ }^{55}$ The Court's method to the presence of pregnancy as a proof of guilt is also inconsistent in a number of different cases. ${ }^{56}$ Also the requirement of four male eye witnesses was declared to be contrary to Quran and Sunnah as well as natural laws itself. ${ }^{57}$ The courts have in past tried to keep a balance between the protection of human rights as well as the norms of Shariah. The insertion of article 10-A in the Constitution has further widened the scope of ensuring fair trial rights. There is a gradual but consistent development of fair trial rights due to wide and diversified interpretation of article 10-A of the Constitution. The recent decision by a seven-member bench of Supreme Court has stated in Yousaf Raza Gillani case that the right to be provided with fair trial to the accused has been recognized for a long time in the Constitution and with the introduction of article 10-A, became 'well entrenched in our jurisprudence'. In the constitutional and judicial system of Pakistan, Islamic aspect is predominant. ${ }^{58}$ However, the ruling of the court still favors that protection of human rights especially fair trial rights must not be in conflict with the norms of Islam and Shariah. ${ }^{59}$

The introduction of article 10-A has been hailed as a positive and much needed step towards protection of trial rights. Although Islam is a complete code of conduct, under whose guidelines elaborating right to fair trial gives it more scope and meaning but present judicial system is seen to be at a defensive position regarding human rights. One of the major reasons is the fact that the first widespread and much publicized campaign of Islamization was not been well planned and revolved around punishments. Those punishments gradually concentrated on very few areas of criminal law like zina, rape, khamr (wine) and blasphemy. Economic and social reforms, trial proceedings and criminal law and other important arenas were largely ignored. This is also partly due to the cry foul by the information dispensing agencies in Pakistan. In present time, Islamization of judicial system in Pakistan is related to confusion, misunderstanding and stereotyping. The scope of making criminal laws especially fair trial rights in accordance with Islam seems, at present to be quite bleak.

\section{Conclusion}

Pakistan was created in the name of Islam and the general masses have a strong and binding attachment with their religion. This is because out of the two parts, one is of belief and the other is about the rules and regulations of living life in Islam. Since the belief is not only inflexible but to have flexibilities and doubts amount to leaving the membership of the religion, it is always the rules and conducts that are subject of debate. More so in Subcontinent and then in Pakistan, the time period is relatively recent, and many religions and cultures have amalgamated in this region. The lack of strength in institutions and the personal preferences of the democratic and dictator 
rulers have pulled the legislation in opposite directions too many times. The result is a hotchpotch of laws with no clear sense of belonging. ${ }^{60}$ The inefficient implementation has led to further confusion about the association of laws especially criminal laws. The right to fair trial has been provided in Islam in clear words, the practical application and benefits of which had been observed in peaceful and thriving Muslim communities for centuries. The effort of Islamizing legislation itself has created an impression of cruelty and inhuman treatment of the accused in Pakistani society. But this is more to do with incomplete and not in-depth study of Shariah laws. If Shariah laws are implemented in their true letter and spirit, society in Pakistan would go as close to perfection as possible, but the current situation is totally opposite where the name of Shariah and Islamic Laws is synonymous with barbarism and terrorism. It is a long way to go for the laws to be created and implemented according to the true spirit of Islam. The introduction of article 10-A of the Constitution has been a commendable act but introduction of Islamic provisions in providing right to fair trial can introduce further refinement in legislation pertaining to trial rights in Pakistan.

\section{References.}

${ }^{1}$ Eaton, Gai. Islam and the Destiny of Man. SUNY Press, 1985. Pg 166-167.

${ }^{2}$ Von Grunebaum, Gustave E. Medieval Islam: a study in cultural orientation. University of Chicago Press, 2010. P346.

${ }^{3}$ https://www.ukessays.com/essays/philosophy/the-nature-and-purpose-of-shariah-philosophyessay.php (accessed on 4th august 2019 at 4:39 am.)

${ }^{44}$ Ibid 3, pg. 167.

${ }^{5}$ Iqbal, Khurshid. The right to development in international law: the case of Pakistan. Routledge, 2009.

${ }^{6}$ Kamali, Mohammad Hashim. Principles of Islamic jurisprudence. Cambridge: Islamic Texts Society, 1991. Pg 19-20. Seealso Coulson, Noel J. "The state and the individual in Islamic law." International \& Comparative Law Quarterly 6, no. 1 (1957): 49-60. Kamali tells of 350-500 verses dealing with legal matters while Coulson considers 80 verses.

${ }^{7}$ Iqbal, Khurshid. The right to development in international law: the case of Pakistan. Routledge, 2009.

${ }^{8}$ Rahman, Fazlur. "CONCEPTS SUNNAH, IJTIHĀD AND IJMĀ'IN THE EARLY PERIOD." Islamic Studies 1, no. 1 (1962): 5-21.

${ }^{9}$ https://www.islamweb.net/en/article/151024/the-sunnah-the-second-source-of-legislation (accessed on 17th January 2018 at 4:23 am.)

${ }^{10}$ Ibid 3, pg 168.

${ }^{11}$ Ali, Abdullah bin Hamid. "Scholarly consensus: Ijma ‘: between use and misuse." Journal of Islamic Law and Culture 12, no. 2 (2010): 92-113.

${ }^{12}$ Ibid 3 pg 167.

${ }^{13}$ The Holy Quran 4:59.

${ }^{14}$ Narrated by al-Tirmidhi (4:2167), ibn Majah (2:1303), Abu Dawood, and others with slightly different wordings.

${ }^{15}$ Kayadibi, Saim. "Ijtihad by Ra'y: The Main Source of Inspiration behind Istihsan." American Journal of Islamic Social Sciences 24, no. 1 (2007): 73.

${ }^{16} \mathrm{https}$ ://islamicbankers.files.wordpress.com/2015/08/qiyas-71.pdf (accessed on 6th February 2019 at 5:37 am.)

${ }^{17}$ Bassiouni, M. Cherif. "The individual Human Rights and Habeas Corpus Islam." Jami 'ah al Falh Publications, Karachi (1972): 557.

${ }^{18}$ Kamali, Ibid. pg. 76. 
${ }^{19}$ Watt, W. Montgomery, and W. Montgomery Watt. Islam and the Integration of Society. Routledge, 2008. Pg 234.

${ }^{20}$ Nasr, Seyyed Hossein, Titus Burckhardt, and Huston Smith. Ideals and realities of Islam. London: Allen and Unwin, 1975. Pg 98.

${ }^{21}$ Thornely, J. W. A. "Jowitt's Dictionary of English Law. By the late the Right Honourable the Earl Jowitt and Clifford Walsh, 1l. m., Solicitor of the Supreme Court. by John Burke, Barrister, Sometime Editor of Current Law.[London: Sweet \& Maxwell Ltd. 1977. 2 Vols.: vii, 1,922 and (Bibliography) 13 pp.£ 45. 00 net.]-Osborn's Concise Law Dictionary. by John Burke, of Lincoln's Inn, Barrister-atLaw.[London: Sweet \& Maxwell Ltd. 1976. vii, 352 and (Law Report Abbreviations \& Regnal Years) 43 pp. Cased.£ 3. 25; paperback,£ 2 ...." The Cambridge Law Journal 37, no. 2 (1978): 350-351.

${ }^{22}$ A.I.R, 1943 P.C 164.

${ }^{23}$ Chapter $1^{\text {st }}$ of the Constitution of Pakistan, 1973.

${ }^{24}$ http://www.pakistani.org/pakistan/legislation/constituent address 11aug1947.html (accessed on 17th February 2019 at 5:39 am.)

${ }^{25}$ Vikør, Knut S. "The Sharia and the nation state: Who can codify the divine law?." The Middle East in a globalized world (1998).

${ }^{26}$ Ibid

${ }^{27}$ Schmid, Konrad. "In the Name of God? The Problem of Religious or Non-religious Preambles of State Constitutions in Post-atheistic Contexts." Occasional Papers on Religion in Eastern Europe 24, no. 1 (2004): 3.

${ }^{28} \mathrm{Haq}, \mathrm{Mahfuzul}$, and MAHFUZUL HUQ. "Some Reflections on Islam and Constitution-Making in Pakistan: 1947-56." Islamic Studies 5, no. 2 (1966): 209-220.

${ }^{29}$ Kennedy, Charles H. "Repugnancy to Islam-Who Decides? Islam and Legal Reform in Pakistan." International \& Comparative Law Quarterly 41, no. 4 (1992): 769-787.

${ }^{30}$ State v Zia ur Rehman, PLD 1973 SC 49.

${ }^{31}$ Art. 1 and 2 of Art. 41 of the Constitution of Pakistan 1973 provides that both the President and the Prime Minister shall be Muslims.

${ }^{32}$ The 1973 constitution, Art. 227.

${ }^{33}$ Mehdi, Rubya. The Islamization of the Law in Pakistan (RLE Politics of Islam). Routledge, 2013. P84-102.

${ }^{34}$ Hayat, Qamar. "The Council of Islamic Ideology as a Constitutional Institution: A Critical Analysis." PhD diss., 2017.

${ }^{35}$ Iqbal, Javid. "Islamization in Pakistan." Journal of South Asian and Middle Eastern Studies 8, no. 3 (1985): 38.

${ }^{36}$ Abbas, Hassan. Pakistan's Drift into Extremism: Allah, the Army, and America's War on Terror: Allah, the Army, and America's War on Terror. Routledge, 2015.

${ }^{37}$ Iqbal, Khurshid. The right to development in international law: the case of Pakistan. Routledge, 2009. ${ }^{38}$ Art. 203(C) of the Constitution, the Federal Shariat Court consist of eight Muslim judges, including three judges from among Ulema, who are, or have been qualified to be judges of the High Court.

${ }^{39}$ Under Art. 203D, such law shall cease to have effect on the day the decision of the Court becomes effective.

${ }^{40}$ Iqbal, Khurshid. The right to development in international law: the case of Pakistan. Routledge, 2009.

${ }^{41}$ Eaton, Gai. Islam and the Destiny of Man. SUNY Press, 1985.

${ }^{42}$ Imran, Rahat. "Legal injustices: The Zina Hudood Ordinance of Pakistan and its implications for women." Journal of International Women's Studies 7, no. 2 (2005): 78-100.

${ }^{43}$ Cheema, Moeen H. "Cases and controversies: pregnancy as proof of guilt under Pakistan's Hudood Laws." Brook. J. Int'l L. 32 (2006): 121.

${ }^{44}$ The Qanun-e-Shahadat order (the law of evidence) 1984. 
${ }^{45}$ Iqbal, Nasira. "Legal Pluralism in Pakistan and Its Implications on Women's Rights." Scratching the Surface: Democracy, Traditions, Gender (2007): 101.

${ }^{46}$ Art. 203 DD. Constitution of Pakistan 1973.

${ }^{47}$ https://www.bartleby.com/17/1/62.html (accessed on 17th November 2019 at 4:37 am.)

${ }^{48}$ According to this law, rape is now a tazir offence punishable with death or life imprisonment, fornication (zina) is punishable with five years' imprisonment and a fine of up to ten thousand rupees. A complaint of these offences can now be made to the Court (instead of to the police).

${ }^{49}$ Iqbal, Nasir. "Hasba clauses ruled contrary to constitution: NWFP governor may not assent to law: SC." (2005).

${ }^{50} \mathrm{Lau}$, Martin. The role of Islam in the legal system of Pakistan. Brill Nijhoff, 2005. Pg.9

${ }^{51}$ Haji Nizam Khan v Additional District Judge, Lyallpur, PLD 1976 Lahore 930 and 950. This case was approved by the Supreme Court in PLD 1982 SC 139; for a similar precedent see also Fazlul Quader Choudhry V Muhammad Abdul Haq, PLD 1963 SC 486; it was held that the courts can scrutinize the acts of other branches like the executive and legislature, though this power does not give to the Court any practical or real omnipotence at 521).

${ }^{52}$ A. R. Cornelius, Fundamental Rights under Shariat, PLD Journal, 1970, 144-5 at 145.

${ }^{53}$ See sec. 4: (a) while interpreting the statute law, if more than one interpretation is possible, the one consistent with the Islamic principles and jurisprudence shall be adopted by the Court; and (b) where two or more interpretation are equally possible the interpretation which advances the Principles of Policy and Islamic provisions in the Constitution shall be adopted by the Court.

${ }^{54}$ Mst. Taslem vs. The State PLJ 1996, FSC 138.

${ }^{55}$ Muhammad Nawaz vs. The State, 1990 SCMR 886; Muhammad Sadiq v The State, 1997 P.Cr.L.J 546 (FSC); Muhammad Qasim v The State, 1997 P.Cr.L.J 10965 FSC.

${ }^{56}$ See Mst. Jehan Mina v The State, PLJ 1983 FSC 134 9pregnancy was considered sufficient proof) Mst. Siani v The State, PLD 1984 FSC 121 (pregnancy was not considered sufficient proof).

${ }^{57}$ Begum Rashida Patel v Federation of Pakistan, PLD 1989 FSC 95.

${ }^{58}$ Shakir, Naeem. "Islamic shariah and blasphemy laws in Pakistan." The Round Table 104, no. 3 (2015): 307-317.

${ }^{59}$ Zaheer-ud-din vs. The State, 1993 SCMR 1718.

${ }^{60} \mathrm{http}$ ://iri.aiou.edu.pk/indexing/wp-content/uploads/2018/06/DrSiddique-AFKAR-1-1.pdf (accessed on 4th October 2019 at 6:47 am.)

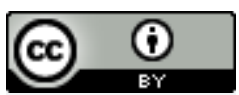

This work is licensed under a Creative Commons Attribution 4.0 International License. 